\title{
Norwegian Christian Leaders: The Term ‘Christian Values' is Divisive and Useless
}

\author{
Hans Morten Haugen $\mathbb{D}$ \\ Faculty of Theology, Diakonia and Leadership, VID Specialized University, 0319 Oslo, Norway; \\ hans.morten.haugen@vid.no
}

Received: 14 September 2020; Accepted: 10 October 2020; Published: 13 October 2020

\begin{abstract}
Church leaders and politicians in several countries make frequent references to Christian values as part of a rhetoric of dividing between wanted and unwanted view and practices. Hence, even more than a source for division between adherents of different faiths, religion divides adherents of the same faith when identifying the core of religion. The article presents findings from a survey and focus group interviews with five groups of Norwegian Christian leaders: church leaders, bishops and deans from the Church of Norway, as well as leaders in mission organization and diaconal foundations. The informants are generally very hospitable towards immigrants, not particularly skeptical of Islam, and highly skeptical of politicians applying the term 'Christian values' for protectionist purposes. While distancing themselves from the term 'Christian values', informants have a clear understanding of what these values encompass. These attitudes mirror the major attitudes among the so-called church-going Norwegians in the Pew report, "Being Christian in Western Europe", having higher appreciation of both Islam and immigration than the other groups of informants. The article proceeds by explaining and contextualizing, including how the churches have promoted conviviality in diverse societies and whether the leaders are willing to act when Christianity is applied to legitimize nativism.
\end{abstract}

Keywords: Christian nationalism; Church of Norway; civilizationism; hospitality; pluralism; Progress Party

\section{Introduction}

The term 'Christian values' is a vague term that can be used by various actors to further their ideologies and interests. It has been increasingly applied by the Christian right, both relating to family policies and immigration. It is the last usage that is of interest in this article. The term 'Christian right' does in this article refer to a broad movement that promotes preservation of traditional values and norms, whose main inspiration comes from certain readings of the Bible, believed to be compatible with a conservative political ideology. Jesus' life and words do, however, often contradict these values, norms, and ideologies, as he did himself not embrace marriage, asked persons to leave their families and property, and embraced strangers and those held in low esteem. Care, compassion, and caring for the common good do often characterize those affiliating with the Christian right, but there are also tendencies towards promoting preservation and maintaining heritage by using an "us versus them" rhetoric.

Appeal to the Christian heritage is often linked with various expressions of Christian right ideology, often with Islam as the defined enemy. Various terms are introduced to describe this appeal: Christianism or civilizationism (Brubaker 2017, p. 1211), Christian nationalism (Whitehead et al. 2018), or "Christendom above Christianity" (Roy 2016, p. 186; see also Roy 2019). This appeal is not particularly strong in Norway, as will be shown below. Nevertheless, there are highly diverse opinions as to what constitutes the core of Christian values. How Christian leaders in Norway understand this 
core and how the increasingly politicized use of the term 'Christian values' is perceived by them is analyzed in this article.

A positive approach towards both immigration and Islam do characterize the so-called church-going Christians in Norway, as will be elaborated more below (Pew Research Center 2018, pp. 21-23). Seen together with survey data among church leaders (Gulbrandsen 2019, p. 128; Gulbrandsen et al. 2002, p. 182), an open attitude towards immigration is perceived to prevail among Norwegian Christian leaders. However, as the elite surveys include only the Church of Norway $(\mathrm{CoN})$ leaders, we have less certainty regarding church leaders from other churches and organizations.

While the term 'Christian values' can be filled with various content, it has been shaped by how the term has been applied in the context of immigration. Iversen, a sociologist of religion, does not attempt at a definition, but he observes: "The rhetoric of 'Christian values' has narrow political appeal unless it comes in a secularized and heritage-oriented tradition ... " (Iversen 2017; own translation). Mathisen, a literary scholar and chief editor of the Christian liberal newspaper Vårt Land (2016-2018), argues that Christian value-adherents do understand Christianity as "the bearer of national identity, something safe and secure in a changeable world" (Mathisen 2019, p. 277; own translation). This is the heritage-oriented understanding that Iversen referred to, linking nation, religion, and tradition.

This article reports the findings from a survey and focus groups' conversations with five groups of Norwegian Christian leaders. The aim was to better understand their view of the term 'Christian values' and associated terms in the context of immigration.

The research question that this article seeks to answer is: How do Norwegian Christian leaders understand the concept Christian values as applied in the immigration debate and how can we explain their attitudes?

After presenting central characteristics of the Norwegian religio-political landscape, seeking to identify the unique characteristics of Norway, and relevant surveys on the church elite-bishops, deans, and National Church Council members and leaders in $\mathrm{CoN}$-and committed Christians in Norway, I will present the method, the main findings from the survey, and then provide explanations and reflections by highlighting main themes from the five focus group interviews.

\section{Norway's Religio-Political Landscape}

In addition to some unique characteristics of Norwegian history, recent surveys do provide relevant insight into the Norwegian context

\subsection{Historical Particularities of Norway}

First, Norway has been a predominantly monoreligious country, with constitutional prohibitions of Jews (until 1851) and Jesuits (until 1956). While other denominations than Lutheran were formally legalized in 1845, there was a prohibition of them teaching religion in school or being school principals until 1969. Still, religious minorities are not adequately accommodated in practicing their religion in Norway (Fox 2020, 2016, pp. 67-68). Moreover, CoN as an established state church was a tool for forced assimilation of, for instance, the Sami and the Romani (living in Norway since the 16th century; the Roma came in the 19th century). The strong integration of CoN in the state apparatus did, however, allow for the influencing of public policies, promoting systems with some basic care for the poor, and gradual expansion of the universalism in the modern welfare state. Notwithstanding this, the Norwegian modern welfare state is also a compromise between the two parties, the Labour Party and the Conservative Party, agreeing on Western security alliances and the universalist welfare state. The awareness of the CoN's past has made persons within $\mathrm{CoN}$ have a high awareness against being a tool for forced assimilation.

Second, the strength of voluntary organizations is noteworthy. These were established already in the first half of the 19th century (Tilly 2007, pp. 30-31). Adding to Tilly's analysis of the role of the Christian movements for the democratic developments in the Nordic states, it is relevant to note that Norway stood out from the other states in the early revival and the central role of women. The early 
impulses were three. First, the overall abilities to read and write-with compulsory schooling being introduced in 1739. A second impulse is the movement created by the lay (and arrested 10 times before 1804 and then being imprisoned from 1804-1811) leader Hans Nielsen Hauge (1771-1824). A third important impulse is the relatively strong movements of independent farmers. These movements have been particularly strong within the mission and diaconal organizations, having developed to become more professional, being both receivers of public funds and, at times, critical of public policies, including in the treatment of foreigners in Norway.

Third, the cautious approach characterizing Lutheran Christianity, resulting from the doctrine of the two kingdoms, has not led CoN to be passive in the political realm. There are two important explanations for this. First, the church struggle during the Second World War, when a strong majority (93.7\%) of the priests disassociated themselves from the collaboration authorities and did not receive their salary. Several joint letters, most noteworthy The Foundation of the Church, published in 1942, justified why a (state) church cannot cooperate with an illiberal state that attempts to bind the conscience of priests, even if that implied that CON "diverged decisively from ... Lutheran theological tradition" (Hassing 2014, p. 263). Second, the impulses from the global church, including the liberation theology and anti-apartheid theologies, were well received in CoN. This impulse has led the CoN and other Norwegian churches to promote justice and human rights in the realm of asylum and refugee policies, working for "a humane asylum and refugee policy" (Christian Council of Norway n.d). Hence, rather than having a Christian 'majority mentality', Norwegian churches can be characterized by having an 'equality mentality', highlighting equal responsibilities regardless of a person's legal status under the prevailing political order.

Fourth, to understand the Norwegian context better, Trägård (2019) identification of the dominant approaches towards altruistic solidarity in the Nordic countries—conditional and unconditional—is deemed relevant. The essence of the conditional approach is that citizens have rights, while the unconditional approach implies that every person residing in a given country has rights. Trägård specifies that notions of national democracy and social democracy are still strong among those promoting the conditional approach in the Nordic countries. This line of thinking has been increasingly challenged by the unconditional approach, building on human rights, internationalism, and the strength of civil society, particularly in Norway, leading to strong tensions between the conditional approach, preferred by most politicians, and the unconditional approach, preferred by most civil society actors. Norwegian churches have over the last decades resisted being tools for an exclusionary nativism-defined by Mudde as comprising nationalism and xenophobia (Mudde 2007, p. 24). This partly contrasts with Denmark, where Danish politicians have defined 'Danishness' - without strong opposition from the Danish majority church. Norwegian churches favor an unconditional approach, and if 'Norwegianness' had been introduced as a term, it would have been resisted, particularly if Christianity were introduced as an element in defining the core of Norwegianness.

\subsection{Recent Surveys on Church Adherence and Views on Immigration}

First, as shown in the introduction, the Norwegian Elite Survey conducted in 2015 revealed that the $113 \mathrm{CoN}$ respondents were more pro-immigration than the other nine elites in Norway (Gulbrandsen 2019, p. 128; Midtbøen and Teigen 2019, p. 71; the total number of respondents is 1352). Similar figures were found in the previous survey, conducted in 2000 (Gulbrandsen et al. 2002, p. 182), which also showed that the CoN respondents were more global in their contacts and more concerned about reducing inequality (Gulbrandsen et al. 2002, pp. 243-44; pp. 179-81)—but less open on gender equality (Gulbrandsen et al. 2002, pp. 130-31). As compared to the USA (Djupe and Gilbert 2009; Crawford and Olson 2001), there are fewer church elite studies in Europe, but Norway is a notable exception.

The Norwegian elite surveys are highly interesting for sociology of religion research. First, Norwegian elite surveys have a large respondent group who are church leaders. Second, several policy areas are addressed. A weakness, however, is that there are only CoN leaders who are informants. The other churches' leaders, and leaders of the diaconal and mission organizations should also be 
regarded as belonging to the church elite. In the survey conducted for this article, I included these other leaders. Even if there were one participant who did not consider herself as Christian, I have nevertheless termed the leaders Christian leaders, and not church leaders, as only three of the surveyed groups represented churches.

Second, as seen above, Norway deviates from the overall Western European pattern where the so-called non-religious are most positive about immigration and least skeptical of Islam (Pew Research Center 2018, pp. 21-23). Among the 15 countries surveyed, it is only Norway where the so-called church-going Christians-being those who attend services at least monthly (Pew Research Center 2018, p. 161) - are the most positive to both immigration and Islam. Most skeptical of immigration and Islam are the so-called non-practicing Christians, who also agree most with the statement "Norwegian [replace] family background is very/somewhat important to be truly Norwegian [replace]" (Pew Research Center 2018, p. 26). Hence, the so-called church-going Christians in Norway have a relatively more open attitude to persons with a foreign background coming to live in Norway.

Third, the same tendency appears in a survey conducted among members of CoN $(n=3016)$, where the so-called believers tend to disagree more with the statement "I believe Norway should accept fewer refugees", compared to the so-called open and so-called rejecters (members who do not consider themselves as believers); the percentages are $32 \%$ (believer), $41 \%$ (open), and $44 \%$ (rejecter), respectively (Opinion 2019, p. 32). There were overall more who disagreed (40\%) than who agreed $(32 \%)$ with the statement (Opinion 2019, p. 31).

Fourth, the Norwegian Election Programme's survey from 2013 has found that the majority of the $40 \%$ who support the statement "We should emphasize a society where Christian values play a greater role" do not themselves report to be believing and/or practicing (Nilsen 2017; see also Ribberink et al. 2017; Doebler 2015, 2014). The terms "emphasize" and "greater role" as applied in the 2013 survey do imply an active endorsement.

Hence, those categorized as being non-practicing in the Pew survey-who can be seen as having a "belonging" relationship to Christianity in the words of Grace Davie (1990)—-tend to be more opposed to immigration compared to those whose relationship to Christianity is categorized as "believing" (Davie 1990) or "behaving"—operationalized as frequency of attendance at services.

From these surveys, I expected to find an overall positive attitude of immigrants among CoN leaders, and a skepticism towards both civilizationalism and Christianism (Brubaker 2017). I also presumed that similar attitudes were dominating among other Christian leaders in my small survey. However, as the minority churches- $\mathrm{CoN}$ is the majority church, with $68.6 \%$ of the population as members-are overall more conservative and have members more identified with the Christian right, it was expected that this might be reflected in some of the attitudes. Some of these, particularly the Baptist Church, have a history of persecution, and the Baptist Church is a result of this very aware of refugee issues.

\section{Method: Focus Group Interviews and Questionnaire}

I conducted focus group interviews with five forums for leaders in churches, mission organizations and diaconal foundations in the period February-May 2020; four of the interviews were done through digital platforms, but the quality of the interviews were not negatively affected, as the technology worked excellently. The first contact regarding the survey and interest of conducting focus group interviews was done in October 2019, after the data collection had been approved by NSD-Norwegian Centre for Research Data. In total, I spoke to 22 persons and received back questionnaires from 27 persons (14 women and 13 men). While the majority of the deans, churches, organizations, and foundation leaders do live in or around Oslo, their birthplace implies that all parts of Norway were represented.

The five questions for the focus group interviews and the 13 statements in the questionnaire, to which the participants were asked to give their scores, were sent to the informants in advance. The informants were therefore well informed about the purpose of the research. When I contacted the relevant persons the first time, I also specified that I would undertake a similar data collection at the other 
four forums, as well as professors and associate professors at six named higher education institutions in Norway, which provide educational programs for various positions in churches (Haugen Forthcoming). Hence, there was transparency on the overall scope of the two studies, and the data collection was done in parallel.

I believe that collecting data from both of these groups has been beneficial, and some comparisons with the views held by academic staff at the higher education institutions are provided at the end of the article. The inspiration for both surveys came from findings in the two Norwegian elite surveys, conducted in 2000 and 2015. As both these elite surveys reveal that CoN leaders had a more global outlook (Gulbrandsen et al. 2002, pp. 273-74), and were the least immigrant-skeptical among the 10 Norwegian elite groups (Gulbrandsen 2019, p. 128; Gulbrandsen et al. 2002, p. 182), it would be highly interesting to get more insight into their motivation and to get the views of other church and organizational leaders.

The five interviews were coordinated differently, with the most assistance provided to me when interviewing CoN bishops and deans; done in association with scheduled meetings. There were attempts at facilitating my interviewing also with the three other groups, but due to various reasons before and during the COVID-19 crisis, I had to contact and arrange with the informants myself. In these three latter cases, each potential informant decided on one's participation.

Since the number of informants is relatively small, it is relevant to give some assessments of what can be derived from the quantitative data. The selection is not representative, partly as a result of self-selection, and partly as a result of the relatively low number of respondents. It may be asked if people who were contacted and who may have immigration-skeptic attitudes that one does not want to expose in a focus group interview, chose not to answer or apologized that they were not able to attend. As issues concerning immigration are discussed rather openly in Norway, and as there is high awareness of the disagreements, I do not consider that the issues were too sensitive to be suitable to discuss in focus group interviews.

The design of the questionnaire and focus group questions will now be further elaborated. In the questionnaire, I formulated the statements to become as short as possible, sought to cover as many policy areas as possible, be concise and avoid terms that are emotional (such as "threat" or "secure"). The informants were asked to consider "the most important factors to consider when faced with immigrants in Norway ..." ", with specific assessments for those in need of protection and those without the need of protection. A few persons chose to tick only for the statements that applied to persons in need of protection. It was also possible to tick off "impossible to answer"; that is, the score 0 , and neither of these were included in the calculation and presentation of the quantitative material. I explained in all focus group interviews that "strongly agree" gives the score 4, while "strongly disagree" gives the score 1 . The fact that I did not choose to include a "neither/nor" middle category that could have increased the scale to 5 was deliberate to enhance the ease for the informants.

However, I also requested the informants to rank the 13 statements from most important $(=12)$ to least important $(=0)$. In the focus group interviews, I explained that it was possible to place the same ranking on different statements. Since a few chose not to rank, and since a few did not rank all statements, I chose not to state the rank with precise numbers, but rather with four levels of tendency, as shown in Table 1.

I chose to formulate the five questions for the focus group interview very generally and without defining terms applied (What are Christian values? Should Christian values define the Norwegian? Should the terms "Christian values" and "Norwegian values" be used in the communication from Christian churches and organizations? Will immigration from outside the EEA affect Christian valuesand if so, how? How should Christian churches and organizations respond to increased immigration to Norway?). I stated in the correspondence in advance that it was entirely possible to criticize both the concepts per se and their use in the public realm. In the focus group interviews, I experienced that precisely because the terms were not specified or defined by me, giving the participants the opportunity to evaluate and criticize both the terms and the use of them, which provided interesting conversations. 
In total, I transcribed 30 pages of text from the focus group interviews, translating the Norwegian into English. This might imply that some important nuances are lost, but I made every effort to make the transcription, the selection of themes, and the coding as precise as absolutely possible. All informants received a draft of the article, invited to give feedback, and approximately one-third did, acknowledging the content of the article.

\section{Overall Findings}

The survey displays an overall welcoming attitude when faced with immigrants who come to Norway, both for those without the need for protection and those in need of protection. In the rest of the article the five groups are referred to as Churches (national church leaders), Mission (mission leaders), Diaconal (diaconal leaders), Bishops (bishops in $\mathrm{CoN}$ ), and Deans (deans in one diocese in CoN).

After presenting the results from the survey, explanations are given by presenting data from the focus group interviews.

\subsection{The Survey: Limited Skepticism}

Table: What do you think are the most important factors to consider faced with immigrants who come to Norway; scores (1-4) for those without the need for protection (top) and in need of protection (bottom). Average score for agreement with 13 statements, from leaders in churches, foundations, and organizations (one decimal). Average score in ranking statements according to importance of 13 statements (0-12): 0-2.9; 3.0-5.9; $\underline{6.0-8.9 ;}$;.0-12.0. (See Table 1).

Table 1. Leaders' Scores and Ranks to 13 Given Statements.

\begin{tabular}{|c|c|c|c|c|c|c|}
\hline & $\begin{array}{c}\text { Churches } \\
(n=5)\end{array}$ & $\begin{array}{c}\text { Mission } \\
(n=4)\end{array}$ & $\begin{array}{c}\text { Diaconal } \\
(n=5)\end{array}$ & $\begin{array}{c}\text { Bishops } \\
(n=6)\end{array}$ & $\begin{array}{l}\text { Deans } \\
(n=7)\end{array}$ & $\begin{array}{c}\text { All } \\
(n=27)\end{array}$ \\
\hline \multirow{2}{*}{ Norway's need for labor } & 3.4 & 3.5 & 2.5 & 3.0 & 2.7 & $\underline{3.0}$ \\
\hline & 1.6 & $\overline{1.5}$ & $\overline{2.0}$ & 1.2 & $\overline{1.2}$ & $\overline{1.6}$ \\
\hline \multirow{2}{*}{$\begin{array}{l}\text { Capacity to integrate, avoid } \\
\text { social exclusion }\end{array}$} & 3.6 & $\underline{3.0}$ & $\underline{3.0}$ & 2.4 & $\underline{3.3}$ & 3.3 \\
\hline & $\underline{2.8}$ & $\underline{2.8}$ & $\overline{3.0}$ & $\underline{1.8}$ & $\underline{2.3}$ & $\underline{2.5}$ \\
\hline \multirow{2}{*}{$\begin{array}{l}\text { Hospitality; humanitarian } \\
\text { values }\end{array}$} & 3.2 & 2.8 & 3.0 & 2.8 & 3.9 & 2.9 \\
\hline & 4.0 & $\overline{3.8}$ & 4.0 & $\overline{3.8}$ & 4.0 & 3.9 \\
\hline \multirow{2}{*}{$\begin{array}{l}\text { Important to protect the } \\
\text { Norwegian }\end{array}$} & 2.2 & 2.0 & 1.5 & 1.3 & 1.9 & 1.8 \\
\hline & 1.6 & 1.0 & 1.6 & 1.0 & 1.2 & 1.3 \\
\hline \multirow{2}{*}{$\begin{array}{l}\text { Cultural diversity is an } \\
\text { enrichment }\end{array}$} & 3.2 & 3.0 & 3.8 & 3.2 & 3.0 & 3.1 \\
\hline & $\underline{2.8}$ & $\overline{2.8}$ & $\underline{2.8}$ & $\underline{3.0}$ & $\underline{2.7}$ & $\underline{2.8}$ \\
\hline \multirow{2}{*}{$\begin{array}{l}\text { Risk of irregular work and } \\
\text { social dumping }\end{array}$} & 3.0 & 2.8 & 2.0 & 3.0 & 2.3 & 2.4 \\
\hline & 2.2 & 2.5 & 1.2 & $\underline{1.8}$ & 1.2 & 1.7 \\
\hline \multirow{2}{*}{$\begin{array}{l}\text { Bible emphasizes hospitality to } \\
\text { foreigners }\end{array}$} & 3.8 & 3.0 & 3.8 & 3.0 & 2.7 & 3.2 \\
\hline & 4.0 & $\overline{3.8}$ & 3.8 & $\overline{3.8}$ & $\overline{3.1}$ & $\overline{3.5}$ \\
\hline \multirow{2}{*}{$\begin{array}{l}\text { More international crime and } \\
\text { terrorism in Norway }\end{array}$} & 1.8 & 1.8 & 1.5 & 2.3 & 1.2 & 1.7 \\
\hline & 1.4 & 1.5 & 1.4 & 1.4 & 1.2 & 1.4 \\
\hline \multirow{2}{*}{$\begin{array}{l}\text { Stimulus for mission work; ties } \\
\text { to global church }\end{array}$} & 3.2 & 3.0 & 1.6 & 2.0 & 2.0 & 2.2 \\
\hline & $\underline{3.0}$ & $\overline{2.3}$ & 1.8 & 2.8 & 2.1 & 2.4 \\
\hline \multirow{2}{*}{$\begin{array}{l}\text { Norway should provide relief } \\
\text { work abroad }\end{array}$} & 2.0 & 3.0 & 2.3 & 2.0 & 1.8 & 2.1 \\
\hline & 1.6 & 2.3 & $\overline{1.6}$ & 1.5 & 1.8 & 1.8 \\
\hline \multirow{2}{*}{$\begin{array}{l}\text { International solidarity and } \\
\text { equalizing injustices }\end{array}$} & 3.2 & 3.5 & 3.0 & 3.0 & 3.4 & 3.1 \\
\hline & $\overline{3.6}$ & $\overline{3.5}$ & $\overline{3.4}$ & $\overline{3.8}$ & 3.8 & $\overline{3.7}$ \\
\hline \multirow{2}{*}{$\begin{array}{l}\text { Islam is incompatible with } \\
\text { national values }\end{array}$} & 1.2 & 2.3 & 1.3 & 1.0 & 1.0 & 1.3 \\
\hline & 1.2 & 1.8 & 1.3 & 1.0 & 1.0 & 1.2 \\
\hline \multirow{2}{*}{$\begin{array}{l}\text { Jesus' example in meeting } \\
\text { those oppressed by others }\end{array}$} & 3.4 & 3.3 & 3.5 & 2.6 & 3.4 & 3.4 \\
\hline & 4.0 & 3.8 & 3.4 & 3.2 & 3.4 & 3.5 \\
\hline
\end{tabular}


We see that there are two statements that are strongly supported by all the groups, particularly for persons in need of protection: "Hospitality embedded in humanitarian values", and "International solidarity and equalizing injustices". Hence, the statements embedded in an unconditional approach (Trägård 2019) and formulated to have a general appeal were those with the highest approval. The more Christian embedded statements (Jesus' example; Bible on hospitality) also received strong scores, particularly for persons in need of protection, and overall got among the highest level on the ranking, with more than 9 on average.

Six statements were more strongly supported when considering persons without protection needs, but the difference is substantial for only one of them: "Norway's need for labor". There are differences also on the scores and rankings to the statements "Capacity to integrate and avoid social exclusion" and "Risk of irregular work and social dumping", but the latter statement has relatively weak scores and moderate ranking. For three other statements, there is a slight difference, but only the statement "Cultural diversity is an enrichment" has a strong score and high ranking. The two statements "Important to protect the Norwegian" and "More international crime and terrorism in Norway" have very weak scores and weak ranking.

I have two reflections to the fact that the scores and rankings for the statements "Capacity to integrate and avoid social exclusion" and "Risk of irregular work and social dumping" are diverse: first, there are some concerns for the societal impacts. Second, the concerns among the informants for ensuring protection for persons in need of protection weigh stronger than the societal impacts.

The statement "Islam is incompatible with national values" receives very low support from all five groups, with a slight exception of Mission. In fact, all informants from Bishops, Diaconal, and Deans ranked this statement as a 0 -for persons without protection needs. Hence, there is very limited appeal in seeing any possible conflicts between Islam and Christianity among the informants.

We also see that the statement "Norway should provide relief work abroad" is not widely supported. This should not be understood as an argument against refugee assistance, but as an argument that the international relief work should not be used to justify more restrictive immigration, asylum, and refugee policies in Norway.

Finally, while the statement "Stimulus for mission and global church" receives support primarily among Churches and Mission, the support for the statement "Cultural diversity is an enrichment" is stronger on average.

Further insight into these responses will now be provided by emphasizing central themes, based on what was covered in the focus group discussions. While there was basic agreement on the problems of the term "Christian values", the emphasis was somewhat different in the different groups. Even if the analysis below will present various topics related to the distinct groups, it will be made clear how the various concerns were shared between the groups.

\subsection{Mission: Values are not Specifically Christian, but Common}

As Mission was somewhat more concerned about Islam than the other groups, it is relevant to start with their reasoning. As a background, it is relevant to characterize the Norwegian mission movement as being relatively conservative, even if this movement has been shaped by various impulses, ranging from Norwegian secularism to the new theological impulses that were identified in Section 2.1 above.

Informants in Mission provided several examples of Christian values, such as loving your neighbor, hospitality, equality, care, self-sacrifice, justice, and mercy. One of the informants emphasized:

I don't want to talk about values that can only apply to Christians, but there are values and words that specifically express Christian faith. What is unique in Christianity are the relationships-to God, man, creation.

By this understanding, to label something as "Christian values" is not considered relevant. The faith - not the values-is crucial. There was no outright rejection of the term "Christian values", however, unlike what will be made clearer when presenting other groups below. One informant in Mission clarified: 
And if asked if Christian values should characterize Norway, I will answer yes. But the diversity that exists in the world, to discover this together, with various understandings of norms and expressions of faith is good for our faith. If you have this approach to Christian values, I believe that it is good for a society. And the word of God and the will of God is good, not only for our faith, but for the whole society.

This long quote appears to imply what can be termed a majority mentality in the beginning and end, and what can be termed an equality mentality in the middle. Some might claim that this emphasis that values derived from a specific faith should apply to the whole society and that the someone can know what is good for others is problematic. Understanding the nuances of what this informant stated, I rather analyze this as representing a position of what everyone who keeps a faith wants, namely to learn about one's faith by encountering persons of other faiths, to be prepared to share one's faith, and always being eager to let one's faith have a real impact in one's life-and through the joint impacts in many peoples' lives, be able to influence society. This informant did not talk about any role of the state in promoting Christianity or Christian values.

The role of the state was, however, brought up by another informant: "And this is the greater danger, that we have a secular state ... " The fear was expressed to relate primarily to the fact that persons who come from a more religious background than secularized Norway do fear that their children will lose their faith when living in a secularized environment. This is the same informant who stressed faith above values, as seen above. This informant's rejection of the term values was, however, not absolute: "if we do not work with Christian values and the Christian expressions in our time, we do not do a proper job".

There was a consistent opposition in all groups, also Mission, to link the terms "Christian values" and "Norwegian values". The term "Norwegian values' was, however, spoken about with a reference to a Norwegian Broadcasting Corporation's series This is Norway [Sånn er Norge]. This program, which was aired in early 2020, presented surveys challenging the perceptions of what characterize Norwegian mentalities, identifying the core mentalities as independence, freedom, and not relying on others-because Norwegians can rely on the welfare state. This mentality has been theorized by Trägård (2014), with Sweden as the case.

While there was agreement that trust might also characterize Norwegian mentalities, hence possible to term a Norwegian value, there was opposition to give this status to the value tolerance. Too much intolerance of deviant position from the liberal mainstream position was given as the reason.

Based on the arguments above, are the positions in Mission actually encompassed by the two terms of the article's title, on Christian values being useless and divisive? The informants in Mission did have two main points. First, the common values above the particular values. Second, faith above values, but a part of the efforts relating to proclaiming one's faith can be to nurture values. Hence, even if the terms "useless" and "divisive" might be somewhat stronger than what was actually said in Mission, I do find that the terms capture the relevant aspects of the conversation in Mission.

\subsection{Diaconal: Christian Values are Understood in a Stigmatizing Way}

The diaconal foundations have come out of the same pious tradition as the mission organizations, and the work has become more structurally oriented, seeking to address the root causes of poverty and social exclusion. Christian faith is not required for ordinary employees in diaconal foundations, merely loyalty to its value basis. Hence, the diaconal foundations have been very explicit on their value basis, seeking to be attractive for employees, public and private funders, and persons receiving the various services.

All informants in Diaconal emphasized an inclusive language, and had several times experienced that labelling something as Christian values was not constructive, as this gives a sense of exclusive ownership. A much better approach is "talking about values as if they were common, and then talking about how we embed our responsibilities as Christians in fulfilling these values". The informants were also positive to speaking about what Christian values are about. 
The term "Norwegian values", however, created unease among the informants. They rather sought terms such as "life in Norway" or highlight which traditions the values are embedded in. The crucial task is to be able to create unity together. Such a task is fulfilled if all members of the society, irrespective of their background, are enabled to articulate something about the society's value basis. This articulation will likely refer to the specific country, but the informants did not believe that it was appropriate to speak about "the Norwegian" in singular.

Various diaconal organizations have different exposure to the realities of diversity in Norway, with those being in charge of hospitals in Oslo West or nursing homes in the districts having less exposure than those engaged in service provision for newly arrived persons or persons without legal residence permits. One working for one of the latter emphasized that some of the staff could report negative experiences concerning the conduct of some of those newly arrived persons who were assisted. Handling these frustrations resulting from inconvenient encounters was said to be a responsibility for the leaders.

From Table 1, we see that there is general support for the statement "Cultural diversity is an enrichment", and the strongest support was expressed by the informant in Diaconal-for persons without the need of protection. These informants did, however, acknowledge that there were many who opposed the arrival of immigrants, even if all longitudinal studies show an increasing acceptance of immigration in Norway, also during the last years (Brekke Jan-Paul and Wollebæk 2020; Strøm 2019; Blom 2017; Hellevik and Hellevik 2017). When seeking to explain the differences in attitudes, one of the informants in Diaconal emphasized the ability to receive, and said that if one has this ability, the encounter is enriching. This ability is not, however, present among everyone, even among one's own staff, as was acknowledged by the informants.

One of the informants-who did not self-identify as Christian, and with a background from a senior position in the public sector-said with regard to a possible situation of increased immigration:

We have a firm foundation, and can combine this with the curiosity when encountering others, as well as respect, we have a lot to contribute in welcoming and integrating these persons into the Norwegian society. We are an unexploited resource. The task relating to the managing of immigration: Can the non-profit sector play an even stronger role, compared to other actors in what can be termed a market? And I believe that non-profit actors-being value-based and specialized-have better capacities.

Rather than understanding this as self-promotion, I understand this to represent an affirmation of a sector that is self-confident in its important contribution to the improvement of welfare, inclusion, and cohesion for persons in Norway. In this context, it is relevant to note that the Norwegian Parliament decided in 2019 to set a target of 10\% for all health and caring services being provided by non-profit actors, and in 2016, the Municipal Council in Oslo set a target of 25\%. Moreover, in public procurement, it is permitted to restrict a tender competition for non-profit actors only, as specified in Section § 26-2a in the regulation on public procurement.

Another issue brought up in Diaconal was competence in understanding faith. It was claimed that this competence was stronger in diaconal institutions than other institutions. It might well be that the politicians and leaders at the diaconal institutions see this competence as an important asset. The individual encounters might, however, be with persons-employees or volunteers-who have no personal faith. I will return to this issue in the discussion.

The tendencies identified above-reluctance about using the term "Christian values", openness for identifying values in an inclusive and inviting manner, and opposition to link the Christian and the Norwegian—characterized all the groups.

\subsection{Churches: Earlier Understanding Challenged by Nationalistic Movements}

The informants from Churches encompassed two Lutherans and three from churches who are strong in the Anglo-Saxon world, with two (Baptist and Pentecostal) representing churches that in 
several parts of the world can be identified with the Christian right. On this background, the opposition shown to the rhetoric and symbols surrounding Christian values is noteworthy.

One informant from one of the latter churches stressed:

What constitutes Christian values was more evident earlier. Now the topic has been challenged by nationalistic movements that are preoccupied with the Christian cross. When asking in the 1960s ... . Today, the issue has been linked to politics, in a different way. Hence, the definition is more diverse than before.

This statement was not challenged by the other informants. Rather, there was a general resentment of politicians and others, one noting: "Christian values have been abused" and another said: "We see a tendency of right-wing extremists cherry-picking symbols, and associate these with Christian values."

Several problems derive from this, as acknowledged by the informants in Churches. One informant said that merely referring to Christian values in the public debate make people tend to ridicule the term as such. The solution to this, as already identified above, is rather to specify these values. Another informant identified a more serious problem, as also identified by Roy $(2019,2016)$ by explaining: "As people tend to differ so much in their concretization of Christian values, we risk that Christian values will be watered down."

All of these acknowledge a serious problem, namely the hijacking of the term Christian values, and hence a potential perversion of what the core of Christianity is perceived to be, at least by those who are relatively uninformed. How many that might have these erroneous views of the core of the Christian religion as concerns welcoming the foreigners is not possible to assess. The problem in much of ordinary media-often concerned with simplifying complex topics-is to present certain views on these topics as being shared by all Christians. This applies for views on same-sex relationships and Palestine-Israel—erroneously presenting all Christians as anti-LGBT or pro-Israel—but so far not for immigration.

Three groups identified the Christian and humanist heritage formulation in Section 2 of the Norwegian Constitution when asked about values: Bishops, Deans, and Diaconal. Except for the term "heritage", Section 2 has no specification as to what this encompasses. The same informant that warned about nationalistic movements above did acknowledge that this embedding implies that Christian values do define the Norwegian. The informant then referred to freedom of expression (section 100) and freedom of belief (section 16) as examples of values recognized in the Constitution.

Compared to the other groups, in Churches, there was less opposition to using the term "Norwegian values". One referred to the welfare society, affirming that "we as a church are a part of civil society that should defend these good bases for our society."

The same informant identified one core aspect of Norwegian mentalities, namely egalitarian structures, noting that many Christians coming to Norway are familiar with much more hierarchical structures, also applying to gender. Hence, Christian values were expected to become more diverse as a result of immigration. Other informants were, however, positive to being challenged in their perceptions.

When asked about how churches and Christian organizations should respond to a possible situation of increased immigration, one informant in Churches said:

We enter a mine field, as I see it. Because on the one side, there might be societal criteria and devices ["innretninger"] that we maybe should not have strong opinions about, but there are issues relating to Christian values where we can respond strongly. [ ... ] At the same time, we must give space to the politicians, so that these have the capacity to integrate, and prevent social exclusion. So we must also consider the societal structures, and we should avoid being perceived as naïve in these issues. As I see it, we must present the Christian values, but be reluctant in presenting specific solutions ...

In this context, it is relevant to observe that the Multicultural Network under the Christian Council of Norway specifies as one of the purposes: "Mobilize ecclesial voices for a more humane asylum and 
refugee policy, be advocates for rule of law for converts, church asylum, residence permits for religious leaders" (Christian Council of Norway n.d; own translation). Hence, the churches have agreed that they should be advocates on at least certain issues within the broader range of immigration policy.

\subsection{Bishops: The Wrong Image of Norway as Monocultural, not Multicultural}

The bishops of $\mathrm{CoN}$ concurred with the others by warning that the term "Christian values" is applied as a marker against others, by certain politicians. Hence, the term merely serves as a label. The specific Christian values, however, were considered most useful, and it was emphasized that Christian values must be embedded in Christian thinking, in defining openness, hospitality, loving your neighbor, justice, forgiveness, and mercy.

On the importance of being embedded in a given tradition, the Swedish Archbishop (1914-1931) Nathan Söderblom was quoted: "Break your chains, and you are free. Uproot your roots, and you die." Hence, there was a strong affirmation of the importance of having a foundation. One of the informants emphasized: "But if you travel in the world you will notice if you are in a Muslim, Buddhist, Atheist or Christian context. Hence, the Christian will have influence, but we have a long way to go." This long way referred to practicing loving your neighbor. There was absolutely no contradiction between having a firm foundation and being open and hospitable, as the informants in Bishops saw it.

This foundation should, however, be understood to encompass diversity. The most interesting part of this focus group conversation was the correcting of the image of Norway being a monocultural country historically. One of the informants specified that the multicultural realities are not merely constituted by Kven, Rom, and Sami; not reflecting upon the fact that the Rom —unlike the Romani, with five centuries' presence-have lived in Norway for less than 180 years. The informant then continued:

And we see it evidently in my diocese that societal progress has come as a result of persons coming to us from other parts of the world, then Swedes and Catholics, who were perceived as strangers and not very popular. So if there is something that is unique to Norway, it is the non-Christian fear for the others.

While this historical fact can be disputed, the main point in the quote is the willingness to refrain from explaining the success of Norway with the efforts of Norwegian-born only. Moreover, the last part of the quote is interesting as the informant presents one Norwegian mentality that is not compatible with what recent surveys show (Brekke Jan-Paul and Wollebæk 2020; Strøm 2019; Blom 2017; Hellevik and Hellevik 2017). The same informant did, however, acknowledge some problems with immigration:

Is the equality culture, that came in the 70s, going to be changed? Is gender equality so strongly embedded in Norway that 2nd and 3rd generations get an equality mentality? I believe it is this aspect of Norwegian culture that people are most afraid of, that it will be lost.

This concern can be responded to by pointing out that persons born in Norway adopt ways of viewing gender equality that differ from their parents born outside of Norway (IMDi 2015, p. 56) and that Norwegians have more negative views of particularly Muslim views than the Muslim views actually are (Sandbu 2012; for similar trends in more countries; see Esposito John L. 2008).

Norway's multiculturalism was also reflected in how churches should respond to a situation of increased immigration to Norway. Three efforts were identified by one informant: (i) prioritize efforts to integrate and fighting racism; (ii) religious dialogue; (iii) accommodate those who come to our churches. While the term "accommodate" was not explained further, a real accommodation must imply that the liturgies and preaching are adjusted so that those who participate do feel at home. The traditional church-goers might have different expectations than the newly arrived church-goers. Hence, the informants from B highlighted the efforts within the churches, including multicultural, multireligious, and multiconfessional accommodation.

In the context of accommodating, competence by Norwegian missionaries who were used to more diversity was discussed. While this competence was generally acknowledged, it was also emphasized 
by one of the informants from B that merely having been a missionary did not in itself provide for competence in accommodating diversity. The accommodating efforts were generally emphasized in B, with accommodation and non-exclusion extending also to persons who might not refer to themselves as Christians. CoN should avoid using terminology implying certain qualifications for being considered a Christian; hence legitimizing a belonging relationship to Christianity, that we saw above, tends to correlate stronger with restrictive views on immigration as compared to the attitudes among active church-goers.

\subsection{Deans: Rejecting the Term "Christian values"}

The informants from Deans were the most explicit in rejecting the term "Christian values" as such. One informant said that this term:

... is applied by persons with whom I tend to disagree very much; as an argument in discussions where we end up with different conclusions. I believe that I also carry Christian values. So the term generates prejudices, in me and probably in others.

The usage of the term is seen as the problem, also by other informants, and this usage was linked to the abuse of power and hegemony, as specified by another informant:

"Christian values" is a way to claim power to define, it is about hegemony, about power, and not about a specific content. There are no Christian values, there are values that exist in our relationships; and that apply to all human beings, all religions.

Later, this informant was admitting one unique Christian value: mercy, but then retracted this.

Mercy and forgiveness, as well as co-responsibility, were identified by an informant, who specified these as representing something specific in the Christian tradition. The fact the term "Christian and humanistic heritage" is the term applied in Section 2 of the Norwegian Constitution was recognized by another informant. Hence, the content of Christian values was acknowledged by the informants, but the term was not.

When seeking to explain this, Brubaker (2017) terms civilizationism and Christianism seems most relevant. These concepts-seeking to explain how a particular form of Christianity and exclusionary forms of nationalism increasingly correlate among many in the West-were implicitly rejected by the informants in Deans. One informant from De referred to Christian values being about "blending culture and religion; the Western world has established a common understanding of the world; these are Christian values, and they have become a part of our culture." This was expressed in a way that must be understood as a rejection of this civilizationism or Christianism, as they imply a hegemonic understanding. This informant also applied the term "propaganda" when describing how the terms "Christian values" and "national values" are concepts used by what was labelled as the "very right-wing" political movement.

Additionally, the term "Norwegian" created resentment, as it was seen as being potentially abused in exclusivist manners. One informant in Deans proposed that "in Norway" should be added-not using the label "Norwegian" —as this was seen as being more inclusive. Similar notions were implicitly addressed in the other groups. Indigenous peoples, national minorities, and immigrant minorities were seen as contributing to conceptions about the Norwegian, and Somalis and Sudanese, and Muslims were specified-by different informants—as contributing to an understanding of what is Norwegian.

The open and non-defined questioning regarding Christian values and the Norwegian were commented by many, one asking if the (populist) Progress Party MP and former Minister Sylvi Listhaug had set the premises for the questions. Another informant stated:

Saying that certain values are embedded in a tradition that can be defined, that is something good. And as with all "goods", this can be abused. And the abuse is when defining, this is about excluding someone; saying that some are "inside" and some are "outside". But it should rather be about nurturing something that is important for us. 
By listening to what this informant said to other questions and the responses to the questionnaire, it is obvious that the "us" must be understood to include all those residing in Norway. By being adequately inclusive, defining everyone to be on the "inside", must imply that the tradition is defined in an inclusive way. We will return to how this tradition can be defined inclusively in the discussion below.

When seeking to identify the proper response to this situation, several informants stressed that the churches must be present in the public debate in order to define what the core of Christian values actually are. As expressed by one of the informants in Deans:

If these concepts are not good concepts, it is important that we take part in the debate; if not, we are perceived as being absent. And I believe that this is necessary, especially if the situation becomes more tense, then the Progress Party is very quick in using these terms.

We see that there is an understanding of a real struggle over ownership of terms. Even the informant who specified that there are "no Christian values", highlighted that churches should be highlighting common values and "what can be termed Christian in a particular time and culture", and by this challenge an established and power-oriented position. For this informant, this was about fulfilling the vision "More heaven on earth".

Finally, the problematic shift of the term integration in the public discourse was commented by one informant in Deans, and a similar concern was expressed by one of the informants in Mission: "There is a difference between integration — become like us—and inclusion—which is more about diversity, to create something bigger." The current understanding, also among public authorities in Norway is to view integration as adaptation (IMDi 2014, pp. 28-30), and that adaptation is the responsibility of the individual, but many can assist in these efforts. This informant in Deans emphasized that it was possible—also for "white" Norwegian congregations—to practice inclusion more than integration.

\section{Discussion}

Five topics of general importance will be discussed in this section: (i) why there are not more skeptical views of immigration expressed, asking whether the selection of the informants and the form of data collection imply too biased findings; (ii) the particular Norwegian value basis, as formulated in Section 2 of the Constitution as well as two legal provisions; (iii) whether Christians have a higher religious "literacy", allowing them to provide for conviviality in diverse societies (Lutheran World Federation and interdiac 2013); (iv) whether and how the Christian leaders respond when Christianity is applied to legitimize nativism, seen above as comprising nationalism and xenophobia (Mudde 2007, p. 24), as there are Norwegians who are both very Christian and very nationalistic (Brekke 2019), even if their precise number is difficult to determine; (v) if the particular roles taken by the churches in Norway can explain some of the attitudes identified.

To the first point, while the methodology was discussed above, it is relevant to repeat that immigration is discussed rather openly in Norway, and it is fully legitimate to disagree. Self-selection was possible in all groups except from Deans, as this focus group discussion happened during a regular coordination meeting. Diaconal was the group where the lowest share of those invited did participate. It might be that persons who were more skeptical of immigration did not respond, but from what I know of Norwegian Christian leaders' attitudes-concurring with the perspective of the oppressed and challenging power abuse and exclusion-there is a very low likelihood that a substantially different picture would emerge if all the leaders contacted actually did participate. Among my informants, there was nobody who can be interpreted to have any sympathy with linking Christianity and nativism—nativism also being rejected by the current Norwegian PM (Solberg 2020)—but such linking is done by some Norwegian Christians, as will be further analyzed below.

To the second point, Section 2 of the Norwegian Constitution says: "Our values will remain our Christian and humanist heritage This Constitution shall ensure democracy, a state based on the rule of law and human rights." What these "our values" are is not specified. In the Education Act and the Kindergarten Act, the purposes of the two are embedded in: 
... fundamental values in Christian and humanist heritage and traditions, such as respect for human dignity and nature, on intellectual freedom, charity, forgiveness, equality and solidarity, values that also appear in different religions and beliefs and are rooted in human rights.

We see that the Christian and humanist heritage are mentioned first, and then other religions and beliefs are also recognized as carrying the six fundamental values.

None of the informants were referring to the latter acts, but several referred to Section 2 in the Constitution. None of them were problematizing what can be seen as an equalizing of Christian and humanist. Regarding the six fundamental values quoted above, intellectual freedom and equality are perhaps the ones that most persons would not link to Christianity, the former because of a perceived conformism within Christianity, and the latter because of the way for instance LGBT persons have been treated by church authorities. I believe it is important to affirm that there are plenty of examples of both conformism and harsh and denigratory treatment of LGBT persons exercised by church authorities. Nevertheless, one of the informants in Bishops referred to the "same rights" or "equal rights" as among the core of Christian values. A more precise way to capture Christian values is to affirm that equal dignity is among the core of Christian values.

To the third point, particularly in the focus group with diaconal leaders, the issue of religious competence was brought up. I do agree that such competence is important in any society characterized by diversity. In a global context, however, Norway is characterized by some form of shyness regarding religion. One does not easily talk about religion. Hence, it is difficult to know if the person acting on behalf of the diaconal foundation is a person of faith, even if many presume that those who work or volunteer are actually Christians. Persons of faith who approach a diaconal center or service and expects to find a person of faith working for a diaconal organization might actually be disappointed. Hence, even if the service is provided, a person of faith could actually have more expectations about the interpersonal meeting than what is actually possible to fulfil.

To the fourth point, all my informants are not only open to immigrants, but do appreciate immigration. An interesting question is how the Christians that Brekke (2019) has encountered-and that represent a certain segment of Christians in Norway-are perceiving the immigrant-liberal attitudes among the church elite. Brekke summarizes their opinions by the term "betrayal of Christianity" (Brekke 2019, p. 8), and it is particularly CoN that is to blame. Except for their literal reading of the Bible, terming them fundamentalists, Brekke does not identify a particular approach that these persons have towards the Bible.

None of the church or organizational leaders referred to these Christian nativists; this was a more common topic in the parallel study of the views held by professors and associate professors at higher education institutions (Haugen Forthcoming). Rather, the church and organizational leaders referred to either politicians, nationalistic movements, right-wing extremists—or Progress Party and its most vocal politician in promoting Christian values, Sylvi Listhaug. The tension between the elite and the grassroots has been identified by Midtbøen and Teigen (2019), and based on what my informants said on other topics, the church and organizational leaders will not attempt to accommodate the concerns of what I term nativist, often islamophobic Christians. Rather it seems that the Christians leaders whom I interviewed will seek to stem what has been described as an increase in ideological anti-Muslim discourses (Døving 2020; see also Hellevik 2020, p. 122, with 39.4\% agreeing completely or rather well with the statement "Muslims pose a threat to Norwegian culture"). The divide between my informants and Brekke (2019) informants seems irreconcilable. This might not be a problem, as one cannot encompass any position. The different opinions on immigration between the church and organizational leaders and the ordinary people-more than $2 / 3$ of which are members of Church of Norway-seemingly do not concern the church and organizational leaders. Rather, they expressed a preparedness to challenge nativism embedded in Christianity.

Doebler's findings, based on the European Social Survey, are interesting, concluding that "believing matters most ... " for Europeans' positive acceptance of immigration (Doebler 2014, p. 79). In contrast, 
those who primarily have a belonging relationship to religion tend to be less tolerant, particularly in Northern Europe. The fact, however, is that the nativist, often islamophobic Christians, might be frequent church-goers. In another article, Doebler finds that holding to what is termed "fundamentalist faith" makes one more likely to be intolerant towards immigrant or national minorities, termed "racially intolerant" (Doebler 2015). This finding should not be read to imply that fundamentalist religious views necessarily go together with skeptical view towards immigrants, but there is a higher likelihood that they do. I believe that this fundamentalism, when coupled with islamophobia, is an important explanation for the attitudes among the nativist Christians who are also a part of the Norwegian Christian mosaic.

To the fifth point, while my article does not allow for a deep elaboration of churches' efforts in the realm of immigration, integration, and naturalization, there is an overall mutual constructive cooperation between the churches on these issues. The churches have been opposing the restrictions so consistently that it is fair to term the churches as part of an asylum opposition. Even if not all the churches are equally active in proposing—or opposing-amendments to the Immigration Act, they jointly convene services to mourn refugees who have died on their way to Europe (Christian Council of Norway 2019).

\section{Conclusions}

When stating that the term "Christian values" is divisive and useless, according to my informants, this does not imply that the informants do not appreciate talking about the content of these values. Particularly the diaconal foundations are very concerned that they must hold values that both make them stand out as having a Christian embedding, but at the same time are able to be inclusive also for persons who might not profess a Christian faith.

The survey presented in Table 1 reveals that the statements highlighting inclusion and justice with a general embedding — not merely a Christian embedding — received the overall highest scores among the informants. Hence, there is a basis for stating that at least the Norwegian Christian leaders who participated in this research do endorse normative pluralism, operationalized as an attitude implying that "diversity is good in itself" (Beckford 2019, p. 17). The terms identified by Trägård (2019) in identifying the unconditional approach in accommodating persons-Christian charity and human rights-embedded in internationalism and notions of an independent civil society, seem to have strong appeal.

Nevertheless, the preservationist statements- "Important to protect the Norwegian", "More international crime and terrorism in Norway" and particularly "Islam is incompatible with national values" - received overall very little support, in contrast with general attitudes among Norwegians, who overall express certain skepticism towards Muslims (Hellevik 2020).

This overall tendency was also confirmed in the interviews, but the various groups had different arguments as to why the term "Christian values" is useless and divisive. The common message from the Norwegian Christian leaders is that churches and Christian organizations should be talking about, promoting, and practicing the values themselves, and challenging those who use the term "Christian values" for creating "insiders" and "outsiders".

The Norwegian context was outlined in the introduction, emphasizing the history of forced assimilation, Christian revivalist movements, and the churches' willingness to challenge power abuse and injustice. Together with the theories seeking to explain how right-wing populist actors have sought to hijack (Roy 2016) Christianity for nationalistic (Whitehead et al. 2018) and often islamophobic purposes, under the guise of civilizationism (Brubaker 2017), I believe that the Norwegian characteristics are relevant in explaining the attitudes identified. These attitudes can be identified as being inclusive of persons and rejecting of exclusivist rhetoric.

While the main tendency in the responses was not particularly surprising, three patterns in the responses were. First, the decisiveness in rejecting a majority heritage thinking, that by some were termed hegemony. Second, the very strong distancing from those politicians who were seen as (ab)using 
the term "Christian values" for preservationist purposes. Third, the openness for the impulses that minorities could provide, irrespective of whether they had lived in Norway for a short time or over a longer period, and irrespective of their religious affiliation.

Funding: This research received no external funding.

Acknowledgments: Thanks to all participants who contributed to the study.

Conflicts of Interest: The author declares no conflict of interest.

\section{References}

Beckford, James A. 2019. Religious Diversity: Sociological Issues and Perspectives. In Political Religion, Everyday Religion. Sociological Trends. Edited by Pål Repstad. Leiden and Boston: Brill, pp. 11-33.

Blom, Svein. 2017. Holdninger til innvandrere og innvandring. SSB Rapport 2017/38 [Attitudes towards Immigrants and Immigration]. Oslo: Statistics Norway.

Brekke, Torkel. 2019. Conspiracy Theory about a Leftist-Muslim Plot against Christianity in Norway. Journal of Religion \& Society 21: 1-15.

Brekke Jan-Paul, Audun Fladmoe, and Dag Wollebæk. 2020. Holdninger til innvandring, integrering og mangfold $i$ Norge. Integreringsbarometeret 2020. ISF Rapport 2020:8 [Attitudes towards immigration, integration and diversity in Norway]. Oslo: Institute for Social Research.

Brubaker, Roger. 2017. Between nationalism and civilizationism: the European populist moment in comparative perspective. Ethnic and Racial Studies 40: 1191-226. [CrossRef]

Christian Council of Norway. 2019. Minnegudstjeneste på Verdens flyktningdag [Service at the refugee day]. Available online: https://norgeskristnerad.no/2019/06/20/minnegudstjeneste-pa-verdens-flyktningdag (accessed on 24 August 2020).

Christian Council of Norway. n.d. Flerkulturelt arbeid [Multicultural work]. Available online: https://norgeskristnerad. no/flerkulturelt-arbeid (accessed on 24 August 2020).

Crawford, Sue E. S., and Laura Olson. 2001. Christian Clergy in American Politics. Baltimore: John Hopkins University Press.

Davie, Grace. 1990. Believing without Belonging: Is This the Future of Religion in Britain? Social Compass 37: 455-69. [CrossRef]

Djupe, Paul A., and Christopher P. Gilbert. 2009. The Political Influence of Churches. Cambridge: Cambridge University Press.

Doebler, Stephanie. 2014. Relationship Between Religion and Intolerance Towards Muslims and Immigrants in Europe: A Multilevel Analysis. Review of Religious Research 56: 61-86. [CrossRef]

Doebler, Stephanie. 2015. Love Thy Neighbour? Relationships between Religion and Racial Tolerance in Europe. Politics and Religion 8: 745-71. [CrossRef]

Døving, Cora Alexa. 2020. "Muslims Are ... " Contextualising Survey Answers. In The Shifting Boundaries of Prejudice, Antisemitism and Islamophobia in Contemporary Norway. Edited by Christhard Hoffmann and Vibeke Moe. Oslo: Scandinavian University Press, pp. 254-73.

Esposito John L., Dalia Mogah. 2008. Who Speaks for Islam? What a Billion Muslims Really Think. New York: Gallup Press.

Fox, Jonathan. 2016. Unfree Exercise of Religion: A World Survey of Discrimination against Religious Minorities. Cambridge: Cambridge University Press.

Fox, Jonathan. 2020. Thou Shalt Have No Other Gods before Me. Why Governments Discriminate against Religious Minorities. Cambridge: Cambridge University Press.

Gulbrandsen, Trygve. 2019. Elites in an Egalitarian Society: Support for the Nordic Model. London: Palgrave Macmillan.

Gulbrandsen, Trygve, Fredrik Engelstad, Trond Beldo Klausen, Hege Skjeie, Mari Teigen, and Øyvind Østerud. 2002. Norske makteliter [Norwegian power elites]. Oslo: Gyldendal Akademisk.

Hassing, Arne. 2014. Church Resistance to Nazism in Norway, 1940-1945. Seattle: University of Washington Press. Haugen, Hans Morten. Forthcoming. Kristne verdier-begrepet fremmer ekskludering og polarisering. Holdninger hos ansatte ved utdanningsinstitusjoner for kirkelig tjeneste. [The Christian values concept promotes exclusion and polarization. Attitudes of employees of educational institutions for church service]. Teologisk Tidsskrift. Submitted. 
Hellevik, Ottar. 2020. Antisemitism and Islamophobia in Norway. A Survey Analysis of Prevalence, Trends and Possible Causes of Negative Attitudes towards Jews and Muslims. In The Shifting Boundaries of Prejudice, Antisemitism and Islamophobia in Contemporary Norway. Edited by Christhard Hoffmann and Vibeke Moe. Oslo: Scandinavian University Press, pp. 108-54.

Hellevik, Ottar, and Tale Hellevik. 2017. Utviklingen i synet på innvandrere og innvandring i Norge [Trends in the view of immigrants and immigration in Norway]. Tidsskrift for samfunnsforskning 58: 250-83. [CrossRef]

IMDi. 2014. Integreringsbarometeret 2013/2014. Holdninger til innvandring, integrering og mangfold [The Integration Barometer 2013/2014. Attitudes towards immigration, integration and diversity]. Oslo: IMDi [Directorate of Integration and Diversity].

IMDi. 2015. Integreringsbarometeret 2013/2014 Innvandring og integrering-holdninger og erfaringer blant personer med innvandrerbakgrunn [The Integration Barometer 2013/2014 Immigration and integration—attitudes and experiences among people with an immigrant background]. Oslo: IMDi [Directorate of Integration and Diversity].

Iversen, Lars Laird. 2017. Sylvi Listhaug frir stadig til Kristen-Norge, og hun er ikke den eneste [Sylvi Listhaug seeks to win amongst Christian Norwegians, and she is not the only one]. VG. May 19. Available online: https://www.vg.no/nyheter/meninger/i/0RA2M/sylvi-listhaug-frir-stadig-til-kristen-norge-og-huner-ikke-den-eneste (accessed on 10 October 2020).

Lutheran World Federation and interdiac. 2013. Seeking Conviviality. Re-forming Community Diakonia in Europe. Geneva: Lutheran World Federation.

Mathisen, Åshild. 2019. Drakampen om kristendommen [The battle for Christianity]. Kirke og Kultur 124: 271-79. [CrossRef]

Midtbøen, Arnfinn Haagensen, and Mari Teigen. 2019. Verdipolarisering i norsk kontekst? Avstand mellom elite og befolkning i holdninger til innvandring og likestilling [Value polarization in the Norwegian context? Distance between elite and population in views on immigration and gender equality]. Politica-Tidsskrift for politisk videnskab 51: 61-81.

Mudde, Cas. 2007. Populist Radical Right Parties in Europe. Cambridge: Cambridge University Press.

Nilsen, Elin Konstad. 2017. Hvem seirer i kampen om kristenvelgerne? [Who wins the battle over Christian voters?]. Available online: https://www.samfunnsforskning.no/aktuelt/nyheter/2017/hvem-seirer-i-kampenom-kristenvelgerne.html (accessed on 24 August 2020).

Opinion. 2019. Medlemsundersøkelse for Den norske kirke 2019 [Membership survey for CoN]. Available online: https://kirken.no/globalassets/bispedommer/nidaros/dokumentmappe/medlemsunders\%C3\%B8kelse\% 202019/sammendrag\%20av\%20medlemsunders\%C3\%B8kelse\%20alle\%20bisped\%C3\%B8mmer.pdf (accessed on 24 August 2020).

Pew Research Center. 2018. Being Christian in Western Europe. Available online: http://www.pewforum.org/2018/ 05/29/being-christian-in-western-europe (accessed on 24 August 2020).

Ribberink, Egbert, Peter Achterberg, and Dick Houtman. 2017. Secular Tolerance? Anti-Muslim Sentiment in Western Europe. Journal for the Scientific Study of Religion 56: 259-76. [CrossRef]

Roy, Olivier. 2016. Beyond Populism: The Conservative Right, the Courts, the Churches and the Concept of a Christian Europe. In Saving the People. How Populists Hijack Religion. Edited by Nadia Marzouki, Duncan McDonnell and Olivier Roy. London: Hurst \& Company, pp. 185-201.

Roy, Olivier. 2019. Is Europe Christian? London: Hurst \& Company, Oxford: Oxford University Press.

Sandbu, Martin E. 2012. Muslimer holder på middelalderske skikker. In Motgift. Akademisk respons på den nye høyreekstremismen [Antidote. Academic response to the new right-wing extremism]. Edited by Indregard Sigve. Oslo: Manifest, pp. 107-18.

Solberg, Erna. 2020. Vestlige Verdier under Press. Available online: https://erna.no/2020/02/17/vestlige-verdierunder-press (accessed on 24 August 2020).

Strøm, Frøydis. 2019. SSB Analyse 2019/12: Holdninger til innvandrere og innvandring [Attitudes towards immigrants and immigration]. Available online: https://www.ssb.no/befolkning/artikler-og-publikasjoner/ folk-flest-er-positivt-innstilt-til-innvandrere (accessed on 24 August 2020).

Tilly, Charles. 2007. Democracy. Cambridge: Cambridge University Press.

Trägård, Lars. 2014. Statist individualism: the Swedish theory of love and its Lutheran imprint. In Between the State and the Eucharist: Free Church Theology in Conversation with William T. Cavanough. Edited by Joel Halldorf and Fredrik Wenell. Eugene, OR: Pickwick Publications, pp. 13-38. 
Trägård, Lars. 2019. Religious Civil Society and the National Welfare State: Secular Reciprocity versus Christian Charity. In Contested Hospitalities in a Time of Migration: Religious and Secular Counterspaces in the Nordic Region. Edited by Synnøve K. N. Bendixen and Trygve Wyller. Abingdon: Routledge, pp. 19-37.

Whitehead, Andrew L., Samuel L. Perry, and Joseph O. Baker. 2018. Make America Christian Again: Christian Nationalism and the Voting for Donald Trump in the 2016 Presidential Election. Sociology of Religion: A Quarterly Review 79: 147-71. [CrossRef] 